\title{
The Perceptions about Computer Assisted Language Learning for L2 Vocabulary Acquisition
}

\author{
Md. Zahangir Alam \\ Access Academy, Asian University for Women, Bangladesh \\ Farhana Binte Mizan \\ Dept. of English, Asian University of Bangladesh, Bangladesh
}

\begin{abstract}
Being the digital natives, instructors and learners of this cutting edge era largely depend on technology to intensify their learning and teaching process inside and outside the classroom. Many devices are found to make language teaching more effecting and alluring for the learners. Arguably, both parties' teachers and students are receiving some benefits after including this addition of modern science in their learning and teaching process. This study focuses on how CALL aids learning and teaching to this integral component of the language. It is found that certain software which were installed in the computer offer learners help immensely to internalize ESL vocabulary. Indeed, accesses of visual imagery on computer screen aids learners make concrete images of uncommon vocabulary which support very effectively $\mathrm{L} 2$ vocabulary acquisition. Most notably the study has found that CALL eases learning points for the special children besides it helps learners retain the vocabulary which they learn. With the availability, teachers can present lesson in realistic fashion which guide learners internalize the L2 vocabulary. Teachers are found ambivalent about including CALL tools in their daily taught lessons as technology always carries some fringe crisis though none expressed any negative feelings about the worth of CALL in case of vocabulary acquisition.
\end{abstract}

Index Terms - digital natives, CALL, ESL, vocabulary acquisition, special children

\section{INTRODUCTION}

Acquiring vocabulary is the striking step for any language learners and the importance of the same component is unavoidable in learning any second language (Laufer, 1986; Llach \& Gómez, 2007; Nation, 1990; Tavìl \& İşìsağ, 2009). It's unarguably true that inter language development commences with this unit of language as it supports the all the skills to be comprehended. (Smidt \& Hegelheimer, 2004 \& (Cobb, 2007; Kern, 1989). Second language learning is always in especial demand in this recent multicultural world and vocabulary knowledge is indispensable to comprehend any language since words transfer meaning in most of the communicating events. According to Seal (1991), word knowledge is key part of communicative competence, and it is essential for both production and comprehension in a foreign language. According to O'Rourke (1974), it affects students' thoughts, actions, aspirations, and success, especially in academic achievement. Studies noted that without an adequate knowledge of relevant vocabulary, students have difficulty performing the tasks required of them both in school and on the job (Harley, 1996; Kolich, 1985). Harley's study revealed a close connection between reading comprehension and vocabulary knowledge.

Unfortunately learning sufficient number of vocabulary is initially almost impossible for ESL learners (Meara, 1982). In Wallace's (1982) words the most frustrating experience in communicating L2 is the inability to use the words that we need to exchange our views. ESL learners feel vocabulary as a barrier in learning L2 as a result they feel like employing different strategies to acquire ESL words (Chamot, 1987 in Jia Li).

The most traditional approach they demonstrate is taking notes, memorization and repetition of the unfamiliar words (Ahmed, 1989; Cohen \& Aphek, 1981; Gu \& Johnson, 1996; Lawson \& Hogben, 1996; O’Malley, Chamot, StewnerManzares, Kupper, \& Russo, 1985). This is the most basic approach of learning L2 vocabulary and most applied approach by the L2 learners around the globe. Even, the studies of Nation (1982) and O'Malley and Chamot (1990) suggest such strategy can be found effective for the beginner level of L2 learners. As the learners improve their level, they shift from memorization to meaning based processing of learning. (Schmitt's (1997). Meaning based learning of L2 vocabulary is seen to be more effective that of the basic rote learning. (Bialystok, 1979; O'Malley et al., 1985). This suggests that the transition to greater "depth of processing"- " "greater degrees of semantic involvement" (Craik \& Tulving, 1975, p. 267) promotes long-term retention (Craik \& Lockhart, 1972). The peak level of learning occurs when learners consciously show their commitment to their learning, actively formulate their vocabulary learning, independently select and fix their learning style. (Ahmed, 1989).

It is found that technology aids language learning and teaching immensely, to focus writing, Raquel (2006) said it may provide a significant support writing instruction for teachers and students. Due to the availability of authentic texts 
and lessons on the World Wide Web, second language learners of this era have incomparable access to develop reading skills and strategies (Brandi and Klaus, 2002; Kern, Ware and Warschauer, 2004). Very little attention is given in order to track out the effectiveness of including technology for teaching and learning ESL vocabulary. Since the inquisitive learners remain busy finding the easier useful approach of learning L2 language and have a knack for technology, it is important to unveil their opinions about using technology in learning process.

Therefore, this study is conducted to unveil the perceptions of teachers and students hold regarding the effect of using CALL tools to acquire L2 language vocabulary.

\section{METHOD}

The research instrument, survey questionnaire, was used to collect data from 30 school students from grade 5 and 6 who were taught ESL vocabulary using CALL system. The questionnaire comprises 20 close ended questions. The students were explained all the questions before they completed the survey. Besides collecting data from the learners, four teachers who use CALL tools to teach L2 vocabulary were interviewed to track out their perceptions about the impact of CALL. The teachers were interviewed with 10 open ended questions and we took written notes of their opinions. Excel Sheet is used to formulate the data collected from the students on the graphs and figures. The institution, Prime Bank English Medium School, follows Cambridge Excel curriculum.

\section{RESUltS AND ANALYSIS}

Few dimensions are considered to show the results which directly alter the findings of the study. The figures based on students' survey are in Appendix-01 and the opinions teachers put regarding CALL in the classroom in order to help acquiring L2 vocabulary are shown on chart in Appendix-02.

The form of computer learners is available with the learners.

It is seen that $53 \%$ and $40 \%$ school students use Laptop computer and Tab respectively. The most antic form of computer desktop is used by only 7 percent students. These figures on different proportions entail the technological improvement and socio-cultural context. This pie chart states that they are very much familiar and connected with all types of devices. Since it is very important for the students to be familiar with the CALL tools which are to be used in the classroom, it is found the total figure of students use either of the tools.

Preferred way of learning $\mathrm{L} 2$ vocabulary

Surprisingly $100 \%$ students have favor for picture showing via projector is really effective with picture-based vocabulary learning, Guessing from electric word chart, Trace effect or Others teaching methods are not followed at all.

Which particular CALL tool did you find helpful for long term retaining of your vocabulary?

Learners prefer Multimedia and Online dictionary mostly in their CALL-based class to acquire L2 vocabulary. $47 \%$ students cast their opinion for Multimedia while $43 \%$ prefer Online dictionary and only 10 percent of the students have preference for other sources.

The form of video annotation that helps most in acquiring $L 2$ vocabulary

In this dimension it is found that $53 \%$ students think that watching animation helps them most in acquiring vocabulary. Beside of this, $40 \%$ students support on watching short video cliffs where only $7 \%$ students think that watching movies also helpful for them in acquiring vocabulary.

Recording Vocabulary by using English Soundtrack from Movies.

Overall, $80 \%$ of the students sometimes record their vocabulary from English soundtrack movies and note them in their book. On the other hand, 20\% students seldom encounter with this process which means they rarely go through it.

\section{Visuals help to L2 Vocabulary acquisition}

The figure for ALWAYS is higher than all other frequencies which is 43 percent which is almost half of the total. The proportion for OFTEN and SOMETIMES doesn't carry much difference though the former one is ahead by 3 percent. None of the students contravene the benefits of visual aids in L2 vocabulary acquisition.

\section{Difficulties in using CALL tools}

In case of facing difficulties of using CALL tools, 47 percent students believe they seldom encounter with difficulties and 43 percent sometimes go through some difficulties. Only 10 percent students often find it tough to use and there is found none of the students who finds CALL tool always complex to use. Surprisingly, none of the students can dare to utter they never encounter with any CALL tool.

Rate of using CALL tools outside the class

Overall, the 60 percent for the students who use often computer outside is higher than them who use always, sometimes etc. The percentage 23 who always spend time with computer outside the class is quite low as compared to the who often operate. The figure for the sometime users is lower than the former duo. Needless to say, no figure is found for the students who never or seldom use computer outside the classroom.

\section{CALL tools motivate learners for $L 2$ acquisition}

To begin with, it can be stated clearly that $83 \%$ students often believe CALL tools and sources add help to keep them motivated immensely to learn L2 vocabulary. As CALL tools make ways of accessing the authentic materials like different visuals and images, students feel livelier and more engaged with any activity. The other 17 percent immerses 
for who sometimes think it motivates them acquiring L2 vocabulary by using CALL. However, no figure is found for the always, seldom and never.

Teachers' feelings about CALL

As teachers were one of the primary subjects of the study, four teachers who use CALL in teaching vocabulary as a medium of instructions were interviewed to find information on different applications of CALL. The teachers placed their distinctive opinions about the application of CAL tools in teaching L2 vocabulary. For most of them, the efficacy of the application of CALL was a central point. The interviewed teachers differed in their views as to the efficiency of CALL. The teachers were all familiar with CALL tools and found the usage of online dictionaries, OHP and many other applications very effective to acquire vocabulary knowledge. One teacher, by the name of Mohosiana believes that watching movies is helpful in increasing vocabulary knowledge. Teacher Ferdous mentioned CALL tools mostly help learners to be engaged in classroom activities and it doesn't consume much time to visualize the lesson. On the other hand, Ms. Zinnat and Mr. Bikram prefer game based vocabulary tasks like puzzles and spelling bee which are played with some software. Even, they feel, these activities can be used for students' assessments. They have expressed that CALL tools make teaching and learning process easy and enjoyable. However, teachers also have mentioned some threats which can't be ignored. Disadvantages include the less supply of electricity, no proper training of teachers in the field of CALL, and lack of proper practice in institutions.

\section{A. Findings and Discussion}

The findings of the current study have revealed the true nature of the research. For proper comprehension and efficacy, only the major results have been discussed below. The subjects have mostly agreed on how the uses of technology and visual aid have helped them acquire new words and vocabulary.

It has been indicated that the learners of the study had positive attitude towards the use of CALL. Majority of the students are very well acquainted with laptops, tabs, smart phones and the like.

a. Not surprisingly, the laptop is the clear winner when learners have to use it for their personal needs. This is mainly due to the laptop's easy portability. Even this form of computer seems affordable for the students.

b. Being digital natives, learners are well informed about the CALL tools. As a result a major shift has been observed away from paper based texts to digital texts online. For instance, $80 \%$ of the students are at ease using an online dictionary. This is due to its easy accessibility and speed.

c. It is a true fact that learning takes place more successfully if it is vi sual. As the data shows, all the learners prefer to learn vocabulary through visual aid. The same is true for animation. It probably captivates their learning style and is proven people learn better when they see it. As per the difference of the learners, some studies have shown 'low verbal-ability learners do not learn vocabulary words better if they have to process both verbal and visual information' (Pluss, Chun, Mayer and Laufer, 1996, 2003) because of their weak learning acquisition.

d. An impressive number of the students take the time to record English vocabulary from English movies and soundtracks. The English Medium students mostly watch English Movies and serials those influence them immensely to learn new words. Naturally they build up high level of fluency in terms of learning L2 vocabulary.

The teachers believe CALL is quite effective in teaching L2 vocabulary. They explain CALL adds help to visualize and materialize, so assigning very authentic activities to the students in the classroom is easy via CALL. The teachers are highly in favor of CALL though in some extent they differ from each other. It is found that CALL tools offer different helps to the teachers in teaching L2 vocabulary. Most of them agree on point that it increases their class time and they can demonstrate the replica of authentic setting. Moreover, there is a variety of CALL tools that students and teachers have options to choose the suitable and favorable tools for themselves regarding on their requirements. It's easy to visualize teaching lesson using many CALL tools. However, in fewer teachers' opinions about the applications and usefulness of CALL tools contradict each other.

Finally, it can be said that in this web-based world CALL is a great implement to obtain the knowledge more effectively and conveniently. In the age of technology, it's pretty hard to avoid the control of many CALL tools in our daily life. So, it is very important to both teachers and students to use such synchronous gloss actively and receive its essence accurately.

\section{B. Conclusions and Recommendations}

Since each research broadens the realm of ideology, it can be said that this research on CALL based vocabulary acquisition too would open a new door of effective learning and teaching process. Undoubtedly computer assisted learning plays a significant role in education, so it is very important to inaugurate CALL into the classroom. The outcome of the research shows a constructive and successful indication that CALLS aids learners L2 vocabulary acquisition. It is found that technology is favorable, supportive and convenient when it is managed accurately. If the implements are managed systematically and the class is conducted with proper instructions then it is obviously possible to prove its achievements.

Both teachers and students are eager to work with CALL for its convenient enrollment. However, accomplishing it significantly its difficulties can be sorted out which may create negative impact even shatter the aim. Well-equipped 
computer facilities, usage of appropriate and engrossing tools for the students, adequate concern on low level students, electricity availability, well-proportioned internet accession, well-trained teachers and systematized curricula are the fundamental issues to make CALL available to help learning process of the learners. Moreover, vocabulary learning is not so easy task for the L2 learners; they are bound to learn a great number of vocabularies to improve their target language. And it is very obvious to forget maximum vocabulary after certain period as they are not using it affectively. In this case, CALL can provide an image, visual or audio or both with a detail usage of the word in a short time which helps the learners not only acquire new vocabulary but also to retain it for long term memory.

\section{APPENDIX A}

\section{Which form of computer do you use for your study?}

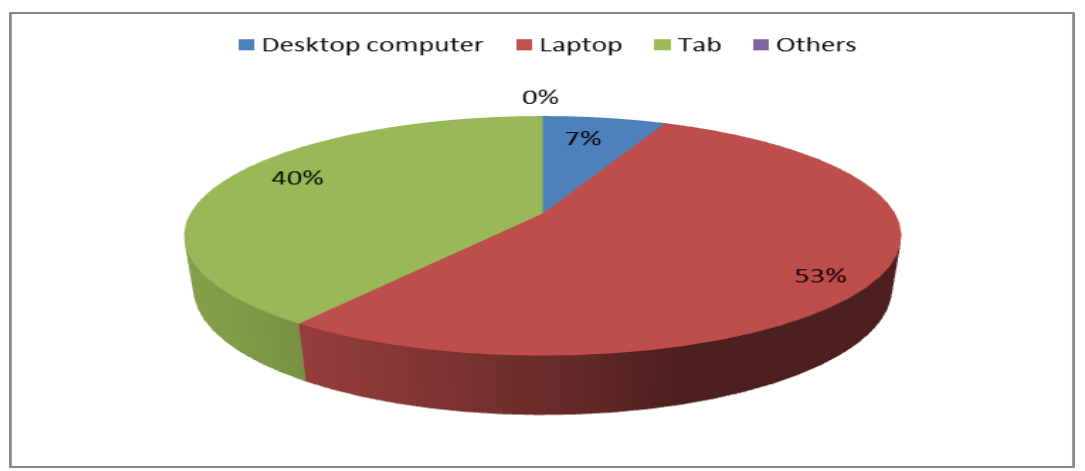

2. Which source do you prefer to know about a new word?

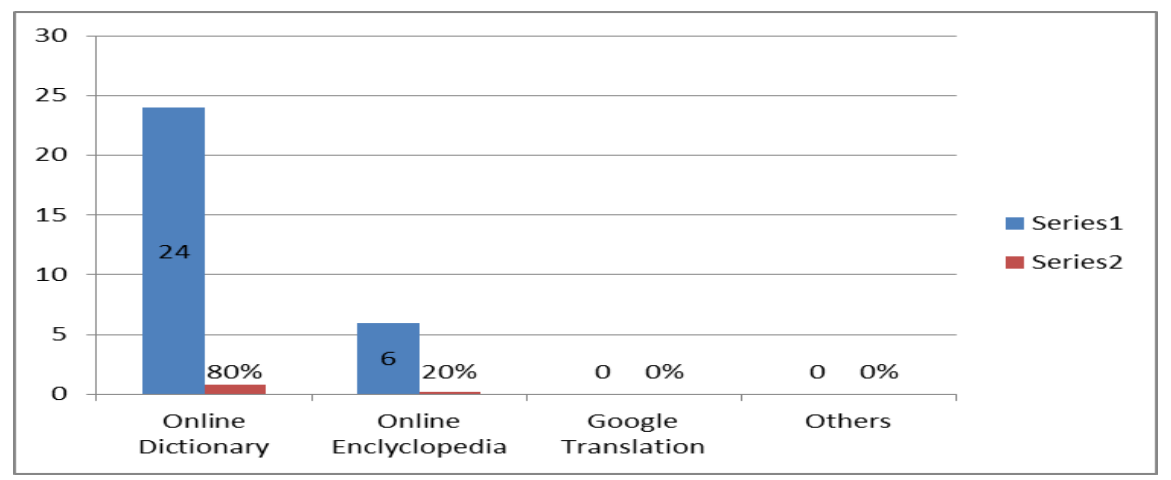

3. What kind of materials do your teachers use to teach L2 vocabulary through CALL?

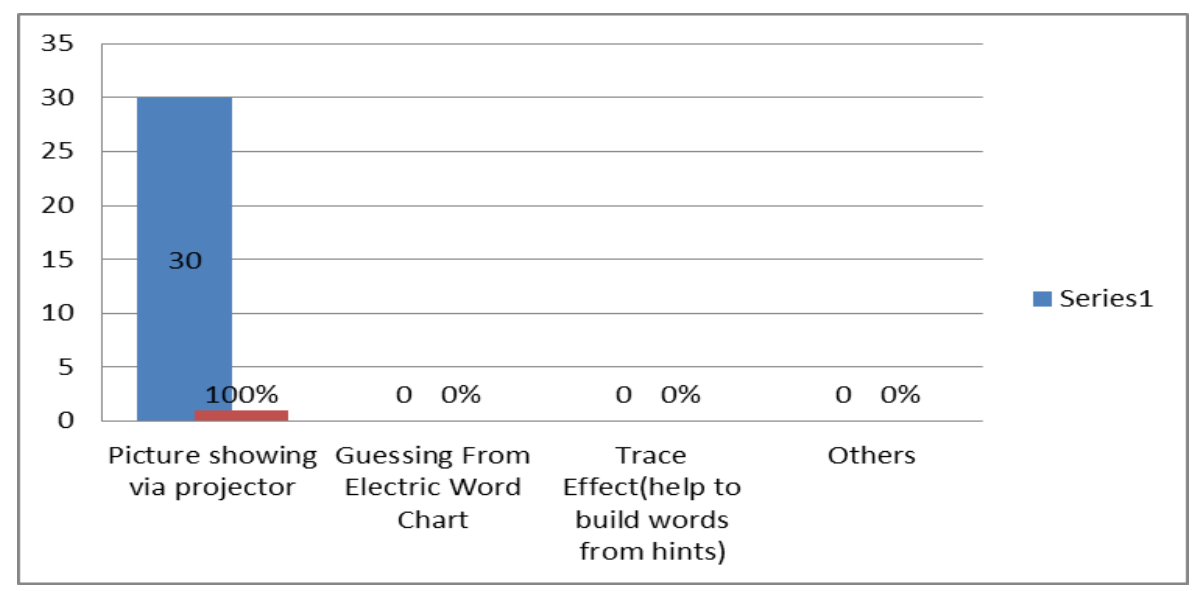


4. Which source do you use to apply new learned L2 vocabulary?

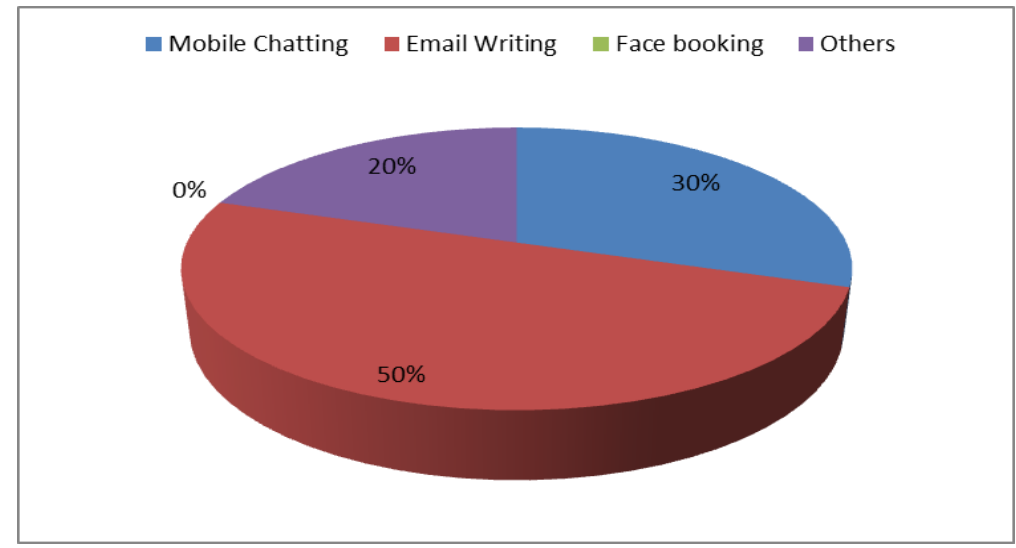

5. Which particular CALL tool did you find helpful for long term retaining of your vocabulary?

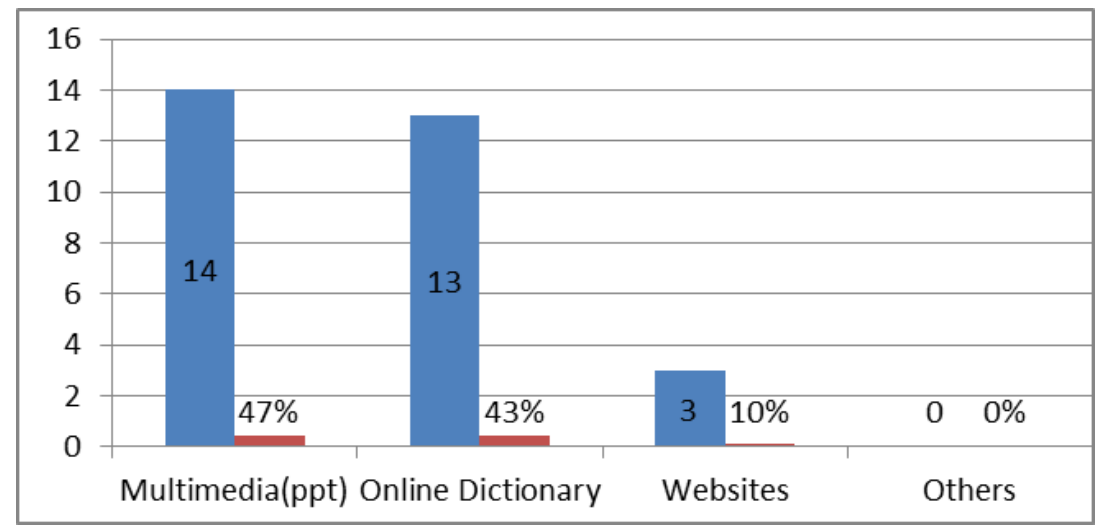

6. Which 12 vocabulary learning website do you use outside the classroom?

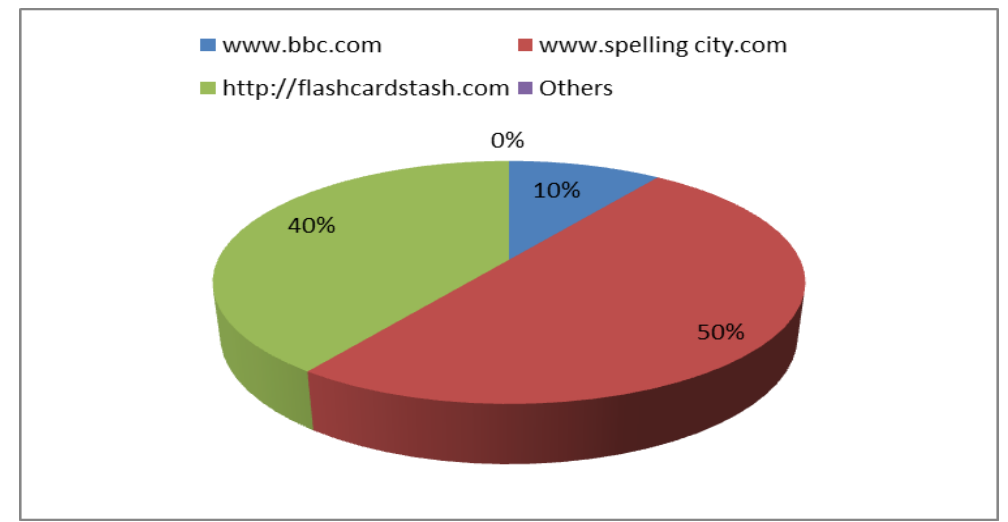

7. Which form of pictorial annotation helps you most in acquiring vocabulary?

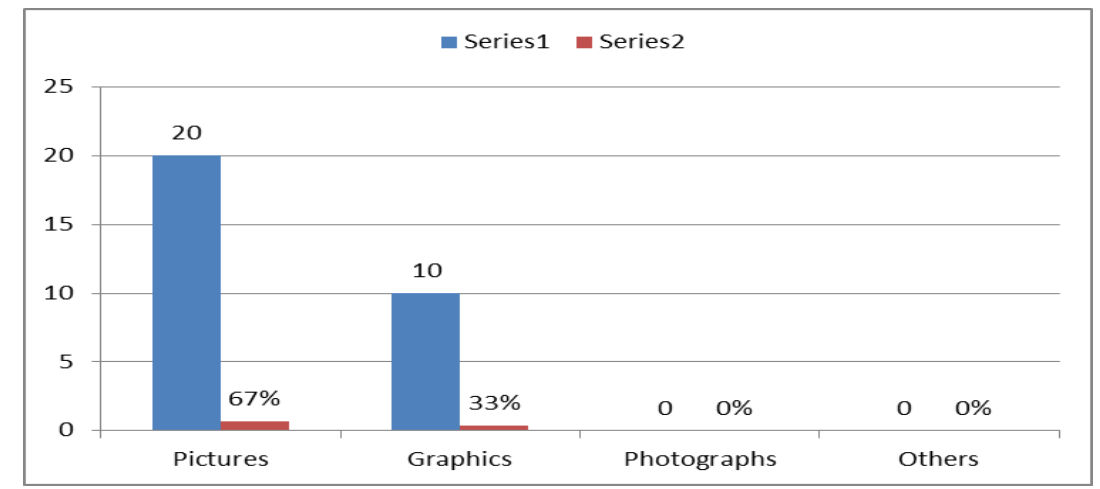


8. Which form of video annotation help you most in acquiring vocabulary?

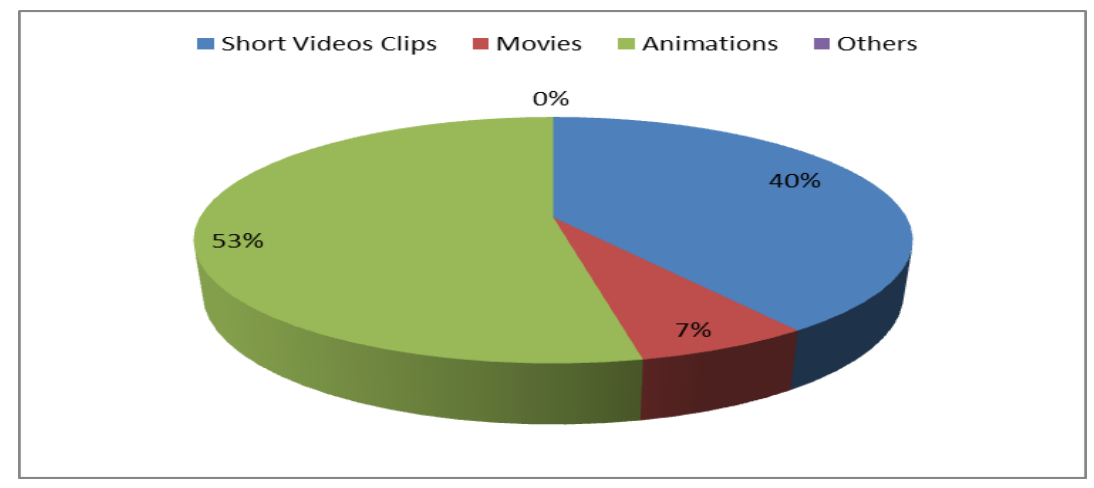

9. Which annotation helps you more when you have hard time?

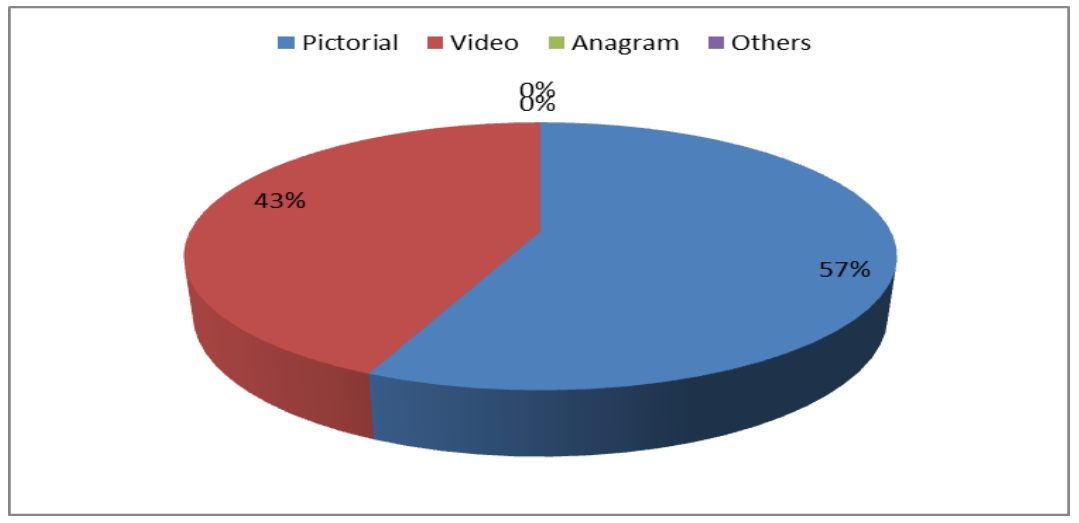

10. Do you use digital dictionary to help translate unknown English words into easier English?

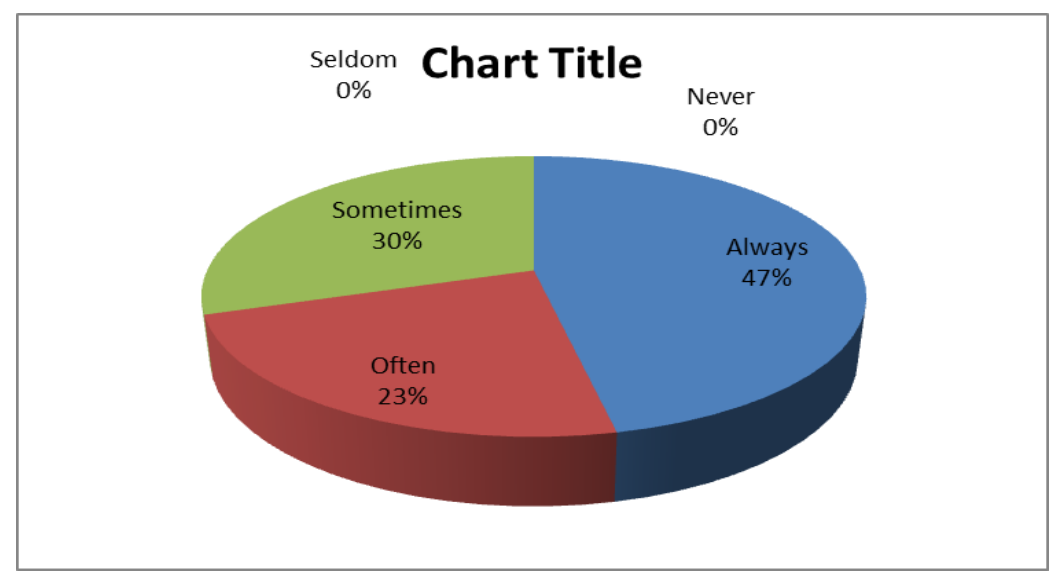

11. Do you use pictures illustrated in the textbook to find the word meanings?

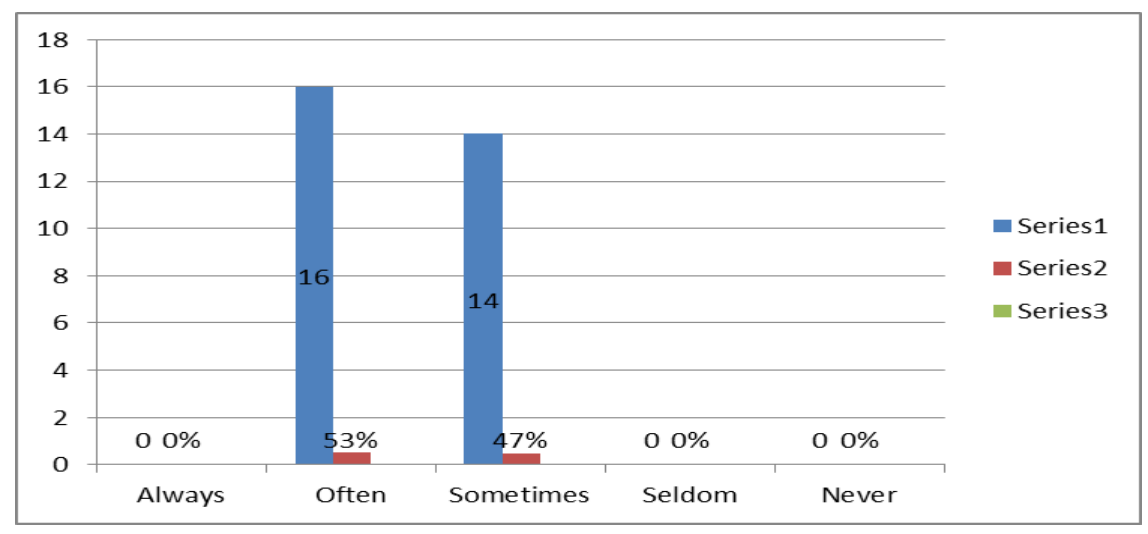


12. Do you write a new word on an insidestoryflash card so you can remember it?

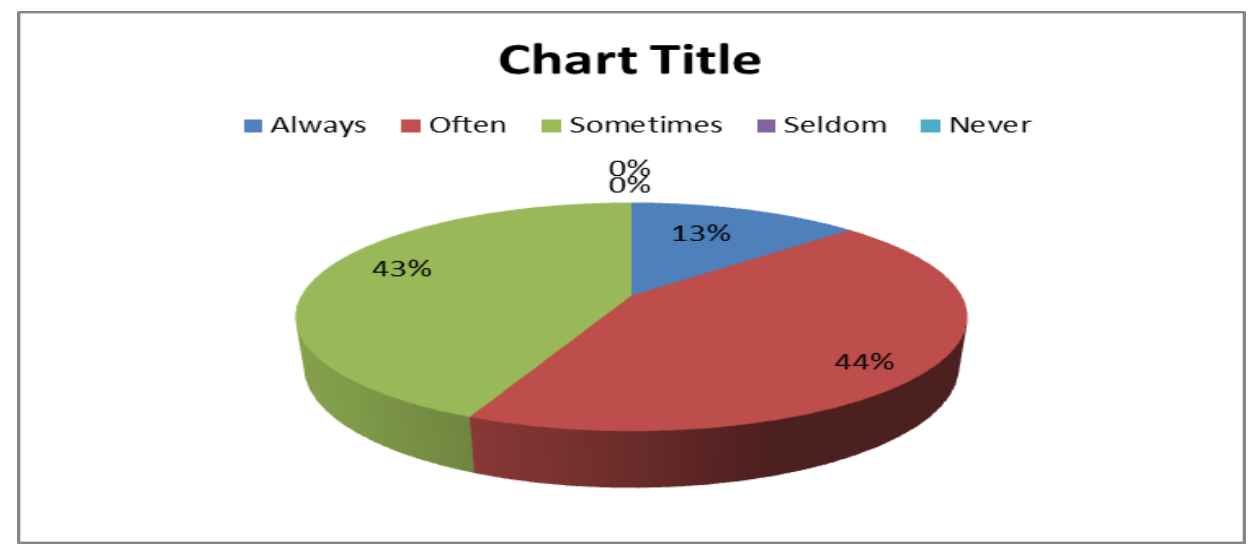

13. Do you record vocabulary from English Soundtrack movies in my notebook?

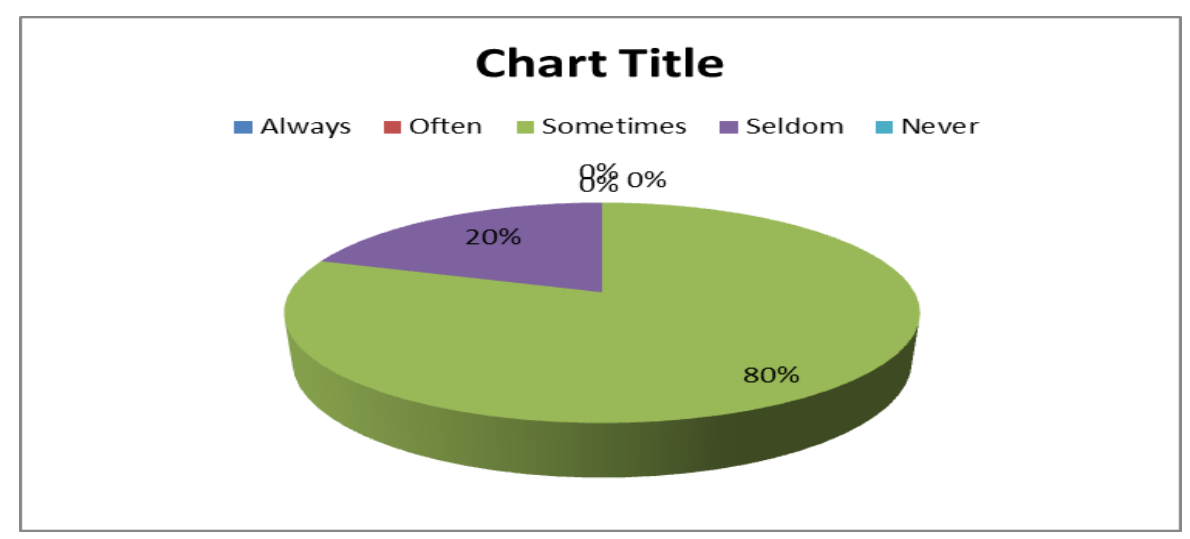

14. Do you use on-line exercise to test my vocabulary knowledge?

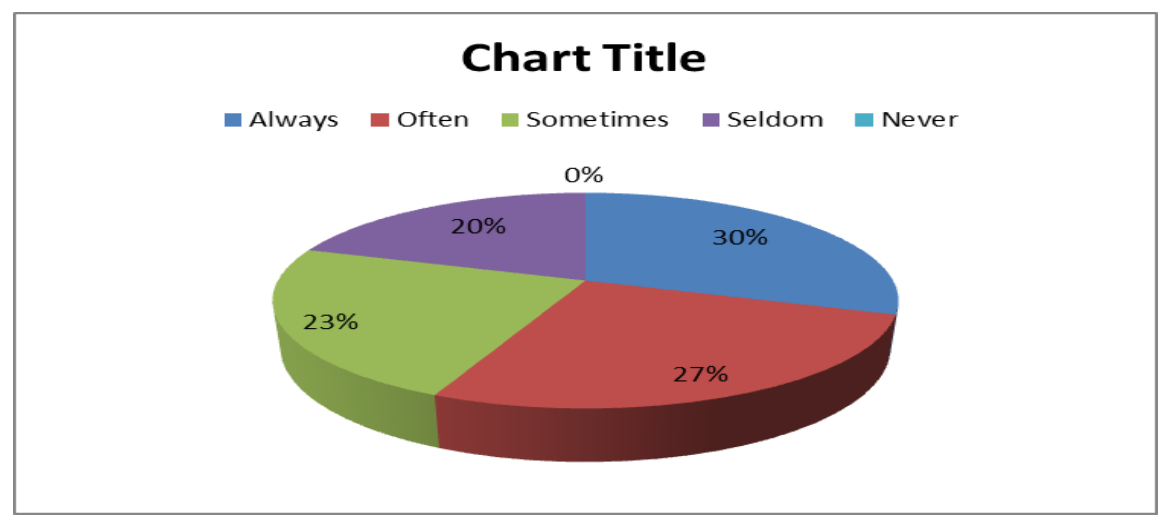

15. When you try to remember the meaning of the words, do you remember the visuals?

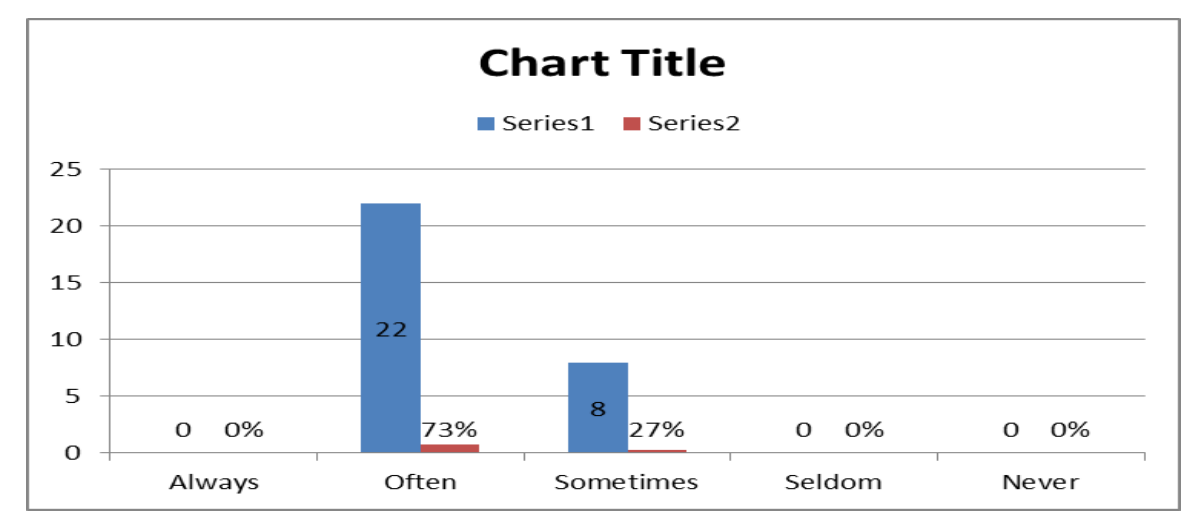


16. Do you find visual aids make $L 2$ vocabulary to remember?

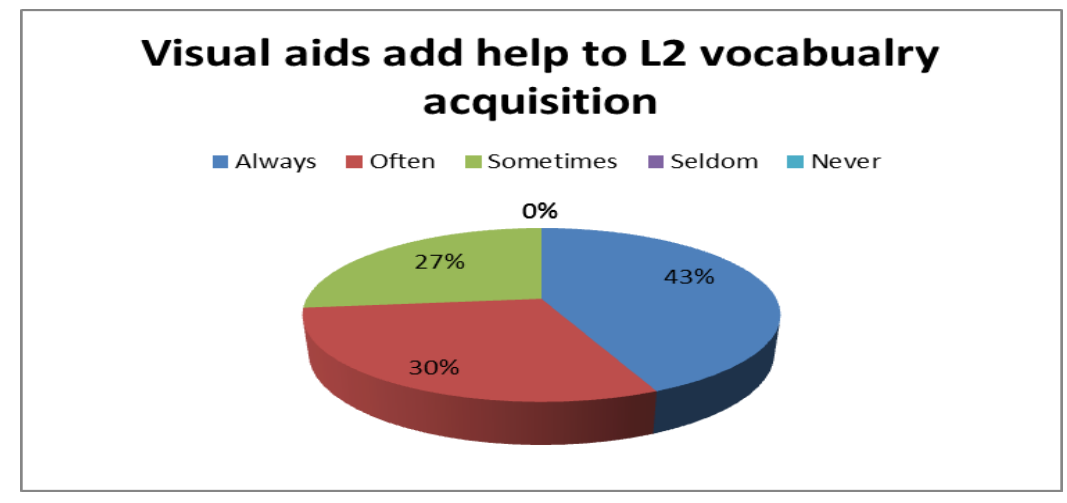

17. Do you find it very difficult to learn through any CALL tool?

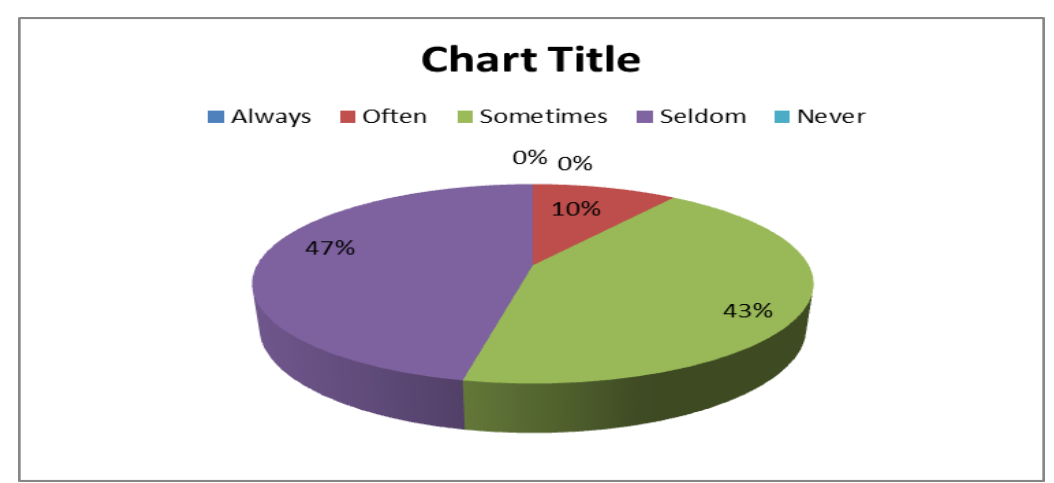

18. How often do you use a computer for vocabulary learning outside the classroom?

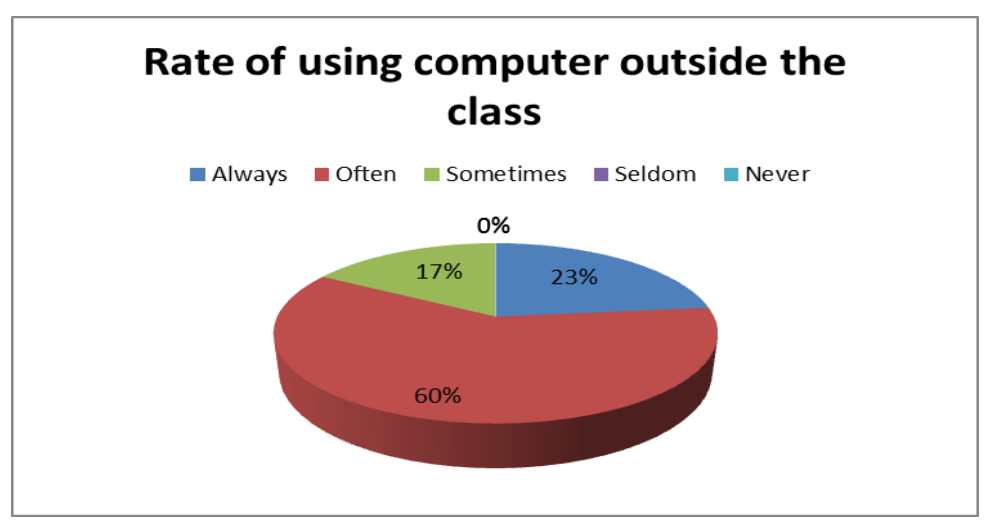

19. How often do you find CALL keeps you motivating?

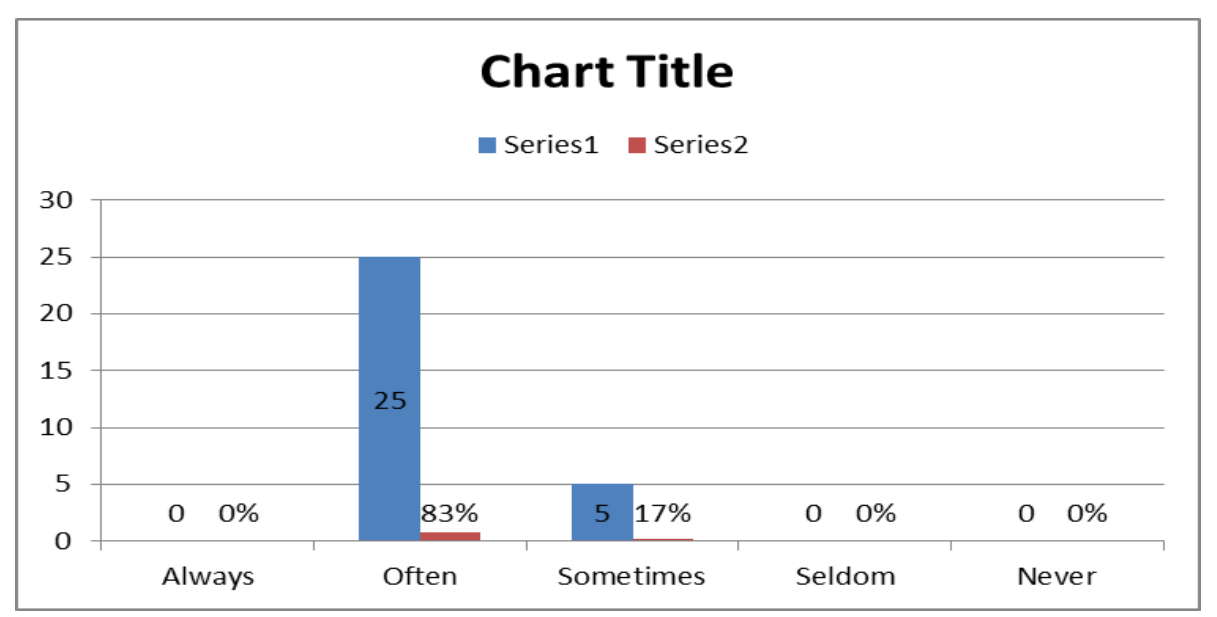




\section{How often do you use Spelling bee site?}

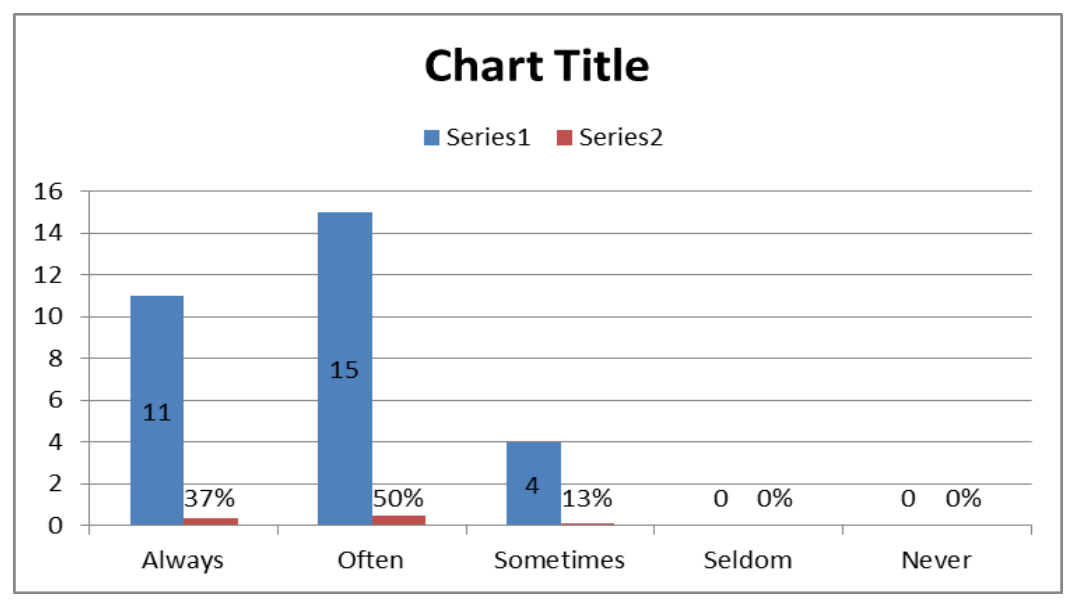

APPENDIX B

Interview questions for the teachers:

1. Did you ever get any training over using CALL?

2. What are the benefits you enjoy by using CALL in teaching vocabulary?

3. Are you comfortable in using CALL in the classroom?

4. What CALL devices do you use particularly in vocabulary teaching classes?

5. Which type of materials do you find more effective in classroom?

6. What are the difficulties you usually face to use CALL device in the class?

7. Which types of CALL tool are mostly effective in long terms vocabulary retention?

8. How do you evaluate students' achievements by using CALL in terms of vocabulary acquisition?

9. Are the students comfortable in using CALL for learning new words?

10. What are the major areas you want to improve of using CALL in the classroom?

\begin{tabular}{|c|c|c|c|c|c|c|c|c|c|c|}
\hline $\begin{array}{l}\text { Teachers } \\
\text { (I) }\end{array}$ & Question 1 & Question 2 & Question 3 & Question 4 & Question 5 & Question 6 & Question 7 & Question 8 & Question 9 & Question 10 \\
\hline Bikram & $\begin{array}{l}\text { Get basic } \\
\text { training and } \\
\text { Class } \\
\text { observation }\end{array}$ & $\begin{array}{l}\text { CALL is } \\
\text { useful }\end{array}$ & $\begin{array}{l}\text { Not } \\
\text { comfortabl } \\
\text { e for using } \\
\text { CALL }\end{array}$ & $\begin{array}{l}\text { Mostly use } \\
\text { Online } \\
\text { Dictionary }\end{array}$ & $\begin{array}{l}\text { vocabulary } \\
\text { games is } \\
\text { very } \\
\text { effective in } \\
\text { classroom }\end{array}$ & $\begin{array}{l}\text { Sometimes } \\
\text { multimedia } \\
\text { did not work } \\
\text { and } \\
\text { electricity } \\
\text { went off }\end{array}$ & $\begin{array}{l}\text { Online } \\
\text { dictionary, } \\
\text { images } \\
\text { using on } \\
\text { some games } \\
\text { like puzzle } \\
\text { are more } \\
\text { effective }\end{array}$ & $\begin{array}{l}\text { Evaluate } \\
\text { students } \\
\text { achievement } \\
\text { by giving } \\
\text { them some } \\
\text { puzzle } \\
\text { games }\end{array}$ & $\begin{array}{l}\text { Some } \\
\text { students are } \\
\text { comfortable } \\
\text { and some } \\
\text { are not in } \\
\text { using CALL }\end{array}$ & $\begin{array}{l}\text { Major areas } \\
\text { like using } \\
\text { latest } \\
\text { multimedia } \\
\text { or other } \\
\text { stuff is very } \\
\text { important }\end{array}$ \\
\hline Ferdous & $\begin{array}{l}\text { Same like } \\
\text { Bikram }\end{array}$ & $\begin{array}{l}\text { Same like } \\
\text { Bikram }\end{array}$ & $\begin{array}{l}\text { Comfortabl } \\
\text { e for using } \\
\text { CALL }\end{array}$ & $\begin{array}{l}\text { mostly use } \\
\text { Multimedia, } \\
\text { Digital } \\
\text { Dictionary, } \\
\text { online } \\
\text { dictionary, } \\
\text { picture and } \\
\text { different } \\
\text { image based } \\
\text { devices in } \\
\text { different } \\
\text { ways }\end{array}$ & $\begin{array}{l}\text { Using } \\
\text { Visuals like } \\
\text { watching } \\
\text { movies to } \\
\text { internalize } \\
\text { the context } \\
\text { of using } \\
\text { certain } \\
\text { words from } \\
\text { movies. }\end{array}$ & $\begin{array}{l}\text { Difficult to } \\
\text { teach that } \\
\text { level of } \\
\text { students } \\
\text { who have } \\
\text { limitation of } \\
\text { using CALL } \\
\text { Tools }\end{array}$ & $\begin{array}{l}\text { Multimedia } \\
\text { projectors, } \\
\text { over head } \\
\text { projectors } \\
\text { and online } \\
\text { dictionary } \\
\text { are mostly } \\
\text { effective }\end{array}$ & $\begin{array}{l}\text { Evaluate } \\
\text { students by } \\
\text { giving } \\
\text { online } \\
\text { vocabulary } \\
\text { test by using } \\
\text { TRACE- } \\
\text { EFFECT } \\
\text { software }\end{array}$ & $\begin{array}{l}\text { Most of the } \\
\text { students find } \\
\text { CALL } \\
\text { useful but } \\
\text { few of them } \\
\text { sometimes } \\
\text { don't enjoy }\end{array}$ & $\begin{array}{l}\text { Need to } \\
\text { Implement } \\
\text { CALL based } \\
\text { training } \\
\text { program }\end{array}$ \\
\hline Mohsina & $\begin{array}{l}\text { Same like } \\
\text { ferdous and } \\
\text { Bikram }\end{array}$ & $\begin{array}{l}\text { Same like } \\
\text { ferdous and } \\
\text { bikram }\end{array}$ & $\begin{array}{l}\text { Comfortabl } \\
\text { e for using } \\
\text { CALL }\end{array}$ & $\begin{array}{l}\text { Same like } \\
\text { Ferdous }\end{array}$ & $\begin{array}{l}\text { Mostly } \\
\text { using visual } \\
\text { materials } \\
\text { and allow } \\
\text { students to } \\
\text { watch } \\
\text { selected } \\
\text { video cliff. }\end{array}$ & $\begin{array}{l}\text { Teaching in } \\
\text { the same } \\
\text { class of } \\
\text { different } \\
\text { level of } \\
\text { students is } \\
\text { tough }\end{array}$ & $\begin{array}{l}\text { Multimedia } \\
\text { projector, } \\
\text { over head } \\
\text { projector } \\
\text { and online } \\
\text { dictionary } \\
\text { are mostly } \\
\text { effective }\end{array}$ & $\begin{array}{l}\text { Evaluate } \\
\text { students by } \\
\text { giving } \\
\text { online } \\
\text { vocabulary } \\
\text { test through } \\
\text { certain } \\
\text { software }\end{array}$ & $\begin{array}{l}\text { Most of the } \\
\text { students are } \\
\text { comfortable } \\
\text { and } \\
\text { motivated in } \\
\text { using CALL }\end{array}$ & $\begin{array}{l}\text { Training } \\
\text { needs to be } \\
\text { ensued to } \\
\text { use the new } \\
\text { CALL } \\
\text { device }\end{array}$ \\
\hline Zinnat & $\begin{array}{l}\text { Not familiar } \\
\text { with CALL but } \\
\text { got training over } \\
\text { CALL while } \\
\text { joined the } \\
\text { school }\end{array}$ & $\begin{array}{l}\text { Same like } \\
\text { mohsina, } \\
\text { ferdous and } \\
\text { bikram }\end{array}$ & $\begin{array}{l}\text { Same like } \\
\text { mohsina }\end{array}$ & $\begin{array}{l}\text { Mostly use } \\
\text { online } \\
\text { Dictionary } \\
\text { and some } \\
\text { useful } \\
\text { websites }\end{array}$ & $\begin{array}{l}\text { Puzzle } \\
\text { games is } \\
\text { effective for } \\
\text { vocabulary } \\
\text { learning }\end{array}$ & $\begin{array}{l}\text { Student was } \\
\text { not familiar } \\
\text { with CALL } \\
\text { so they find } \\
\text { it more } \\
\text { difficult }\end{array}$ & $\begin{array}{l}\text { Tools like } \\
\text { projector } \\
\text { and OHP is } \\
\text { very } \\
\text { effective in } \\
\text { vocabulary } \\
\text { learning }\end{array}$ & $\begin{array}{l}\text { Evaluate } \\
\text { students by } \\
\text { giving } \\
\text { online } \\
\text { assignments } \\
\text { on particular } \\
\text { topic }\end{array}$ & $\begin{array}{l}\text { Students } \\
\text { find CALL } \\
\text { interesting }\end{array}$ & $\begin{array}{l}\text { Institution } \\
\text { should } \\
\text { provide } \\
\text { sufficient } \\
\text { support of } \\
\text { CALL and } \\
\text { be more } \\
\text { careful } \\
\text { about } \\
\text { technology }\end{array}$ \\
\hline
\end{tabular}




\section{ACKNOWLEDGEMENTS}

We feel thankful to the principal Mr.Blass Offelie Saranga Desceller and vice- principal Mr.Mahbub Hossain of Prime Bank English Medium School for giving us an easy access in their institution. We are also grateful to the participants of our survey who co-operated with us in every possible ways. Four teachers who we interviewed deserve special thanks for their time, dedication and most importantly cooperation. We wish good luck of all the people who have any slightest contribution in this study.

\section{REFERENCES}

[1] Ahmed, M. O. (1989). Vocabulary learning strategies. In P. Meara (Ed.), Beyond words (pp. 3-14). London: CILT.

[2] Bialystok, E. (1979). The role of conscious strategies in second language proficiency. The Canadian Modern Language Review, 35, 372-394.

[3] Brandi, Klaus. (2002). "Integrating Internet-Based Reading Materials into the Foreign Language. Curriculum: From Teacherto Student-Centered Approaches." Language Learning and Technology 6: 87-107. 17 Dec. 2002 $<$ http://llt.msu.edu/vol6num3^andl/default.ht.

[4] Chamot, A. U. (1987). The power of learning strategies. Ohio Bilingual-Multicultural Update, 4, 6-11

[5] Chun, D. and J. Plass. (1996a). Effects of Multimedia Annotations on Vocabulary Acquisition. The Modern Language Journal, 80 (ii), pp. 183-198.

[6] Cobb, T. (2007). Computing the vocabulary demands of L2 reading. Language Learning \& Technology, 11(3), 38-63.

[7] Cohen, A. D., \& Aphek, E. (1981). Easifying second language learning. Studies in Second Language Acquisition, 3, $221-236$.

[8] Craik, F. I. M., \& Lockhart, R. S. (1972). Levels of processing: A framework for memory research. Journal of Verbal Learning and Vocabulary Behavior, 11, 671-294.

[9] Craik, F. I. M, \& Tulving, E. (1975). Depth of processing and the retention of words in episodic memory. Journal of Experimental Psychology: General, 104, 268-294.

[10] Gu, Y. Q., \& Johnson, K. R. (1996). Vocabulary learning strategies and learning outcomes. Language Learning, 46, 643-679

[11] Harley, B. (1996). Introduction: Vocabulary learning and teaching in a second language. The Canadian Modern Language Review, 53(1), 3-12.

[12] Hill, M. and Laufer, B. (2003). Type of task, time-on-task and electronic dictionaries in incidental vocabulary acquisition. International Review of Applied Linguistics in Language Teaching, 41(2): 87-106

[13] Kern, R. G. (1989). Second language reading strategy instruction: Its effects on comprehension and word inference ability. The Modern Language Journal, 73(2), 135-149.

[14] Kern, R., Paige, D. Ware, \& Warschauer, M. (2004). "Crossing Frontiers: New Directions in Online Pedagogy and Research." Annual Review of Applied Linguistics 24: 243-60.

[15] Laufer, B. (1986). Possible changes in attitude towards vocabulary acquisition research. International Review of Applied Linguistics in Language Teaching, 24, 69-75.

[16] Lawson, M., \& Hogben, D. (1996). The vocabulary-learning strategies of foreign-language students. Language Learning, 46, 101-105

[17] Llach, P. A., \& Gómez, A. B. (2007). Children's characteristics in vocabulary acquisition and use in the written production. RESLA, 20, 9-26.

[18] Meara, P. (1982). Vocabulary acquisition: A neglected aspect of language learning. In V. Kinsella (Ed.), Surveys I: Eight stateof the-art articles on key areas in language teaching (pp. 100-126). Cambridge, UK: Cambridge University Press

[19] Nation, I. S. P. (1990). Teaching and learning vocabulary. New York, NY: Newbury House.

[20] Nation, I. S. P. (1982). Beginning to learn foreign vocabulary: A review of the research. RELC Journal, 13, 14-36.

[21] O’Malley, J. M., Chamot, A. U., Stewner-Manzares, G., Kupper, L., \& Russo, P. R. (1985). Learning strategies used by the beginner and intermediate ESL students. Language Learning, 35, 21-46.

[22] O’Malley, J. M., \& Chamot, U. A. (1990). Learning strategies in second language acquisition. Cambridge: Cambridge University Press.

[23] O'Rourke, J. P. (1974). Toward a science of vocabulary development. The Netherlands: Mouton \& Co. N.V. Publishers.

[24] Oxford, R. (2006). Effects of Technology-Enhanced Language Learning on Second Language Composition. Hispania, Vol. 89, pp. 358-361. American Association of Teachers of Spanish and Portuguese.

[25] Schmitt, N. (1997). Vocabulary language strategies. In N. Schmitt \& M. McCarthy (Eds.), Vocabulary: Description, acquisition and pedagogy (pp. 199-227). Cambridge: Cambridge University Press

[26] Seal, B. D. (1991). Vocabulary learning and teaching. In M. Celci- Murcia (Ed.), Teaching English as a second or foreign language. Boston, MA: Heinle \& Heinle.

[27] Smidt, E., \& Hegelheimer, V. (2004). Effects of online academic lectures on ESL listening comprehension, incidental vocabulary acquisition, and strategy use. Computer Assisted Language Learning, 17(5), 517-556.

[28] Tavil, Z. M., \& İșìsağ, K. U. (2009). Teaching vocabulary to very young learners through games and songs. EKEV Academy Journal, 13(38), 299- 308.

[29] Wallace, M. (1982). Teaching Vocabulary. London: Heinemann 


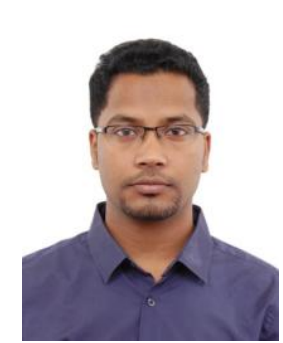

Md. Zahangir Alam, a young researcher, was born in 1989 in Bangladesh who has pursued MA in TESOL in 2016 and CELTA in 2018 from North South University and Cambridge University respectively.

$\mathrm{He}$ is working at Asian University for Women in Chittagong, Bangladesh as an instructor of English. He has published one article regarding motivation and language teaching. The author has esthetic interest in field of assessment, technology and language teaching and so on. Currently, he is working on role of schemata in academic reading and Facebook as a formal instructional environment in facilitating L2 writing.

Mr. Alam is a member of BELTA (Bangladesh English Language Teaching Association).

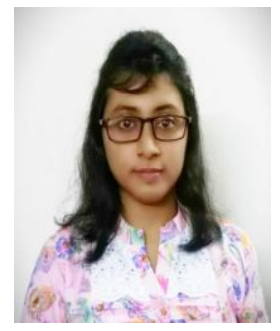

Farhana Binte Mizan is a young researcher from Bangladesh who has pursued BA hons in English and MA in English Language and Literature from Asian University of Bangladesh in 2017 and 2018 respectively.

She is working as a lecturer at Asian University of Bangladesh in the Dept. of English. The author is highly motivated in working in the field of assessment and language teaching, technology and language teaching and so on. At present she is working on Facebook as a formal instructional environment in facilitating L2 writing.

Ms. Farhana has achieved gold medal from the chancellor of the University for being highest CGPA holder from 2008 to 2017. 